\title{
Az ülő életmód és az elhízás fiatalok körében: áttekintő tanulmány a kapcsolódó felmérésekről és oksági elemzésekről
}

\author{
Sedentary behaviour and adiposity in youth: a systematic review of \\ reviews and analysis of causality
}

\author{
Ismertető: Varga Anita $\square$ \\ Országos Gyógyszerészeti és Élelmezés-egészségügyi Intézet
}

Szerzők: Stuart J.H. Biddle, Enrique García Bengoechea and Glen Wiesner

Megjelenés: International Journal of Behavioral Nutrition and Physical Activity (2017) 14:43

DOI 10.1186/s12966-017-0497-8

Beküldve: 2017.09.12.

doi: 10.24365/ef.v58i3.182

Kulcsszavak: ülő életmód, elhízás, okozati összefüggés

\section{ÖSSZEFOGLALÁS}

Az ülő életmód - különösen a tévénézés és az egyéb képernyő előtt eltöltött idő - és az elhízás kapcsolatát vizsgáló tanulmányok száma az 1980-as évek óta jelentős, mégis ez a kutatási terület, a megalapozott kritériumrendszerek hiánya mentén levont következtetések miatt, a mai napig sok bizonytalanságot hordoz magában. Az összefoglaló tanulmány célja, hogy a meglévő szakirodalmak áttekintése és elemzése során - kiemelten az ülő életmód és a testsúly változásának összefüggéseire fókuszálva- választ adjon a következő négy kérdésre. Van-e öszszefüggés az ülő életmód és az elhízás között a fiatalok körében? Ha van összefüggés, befolyásolják-e azt az ülő életmód különböző típusai (pl. képernyő előtt töltött idő, összes üléssel eltöltött idő) és az elhízás különböző markerei (pl. BMI, BMI z-score, derékkörfogat)? Ha van összefüggés, a közepes-erős fizikai aktivitás vagy a táplálkozás képes-e azt mérsékelni? Milyen mértékben lehet okozati összefüggésbe hozni az ülő magatartás és az elhízás közötti kapcsolatot?

\section{KULCSÜZENET A SZAKEMBEREK SZÁMÁRA}

Az áttekintő tanulmány eredményei alapján, a gyermekek és serdülők körében az ülő életmód és az elhízás közötti összefüggés csekély, okozati összefüggés közöttük pedig csak kismértékben vagy egyáltalán nem áll fenn. 